\title{
Characterisation of volatile compounds in an alcoholic beverage produced by whey fermentation
}

\author{
Giuliano Dragone, Solange I. Mussatto, José M. Oliveira, José A. Teixeira* \\ Institute for Biotechnology and Bioengineering (IBB), Centre of Biological Engineering, University of Minho, Campus de Gualtar, 4710-057, Braga, Portugal
}

\section{A R T I C L E I N F O}

\section{Article history:}

Received 12 April 2008

Received in revised form 22 May 2008

Accepted 3 July 2008

\section{Keywords:}

Cheese whey

Continuous fermentation

Alcoholic beverage

Volatile compounds

Kluyveromyces marxianus

\begin{abstract}
A B S T R A C T
An alcoholic beverage ( $35.4 \% \mathrm{v} / \mathrm{v}$ ethanol) was produced by distillation of the fermented broth obtained by continuous whey fermentation with a lactose-fermenting yeast Kluyveromyces marxianus. Forty volatile compounds were identified in this drink by gas chromatography. Higher alcohols were the most abundant group of volatile compounds present, with isoamyl, isobutyl, 1-propanol, and isopentyl alcohols being found in highest quantities $(887,542,266$, and $176 \mathrm{mg} / \mathrm{l}$, respectively). Ethyl acetate had the highest concentration $(138 \mathrm{mg} / \mathrm{l})$ among the esters. Besides higher alcohols and esters, other components, including aldehydes, acids and terpenes were also identified in the whey spirit. Considering that the quality of an alcoholic beverage can be evaluated by the relation between isoamyl alcohol/ 2-methyl-1-propanol and 2-methyl-1-propanol/1-propanol, which have to be higher than unity, it was concluded that a novel spirit of acceptable organoleptic characteristics can be produced by cheese whey continuous fermentation with $K$. marxianus.
\end{abstract}

(c) 2008 Elsevier Ltd. All rights reserved.

\section{Introduction}

Dairy industries generate significant liquid waste, of which, cheese whey is the most abundant. Whey, the liquid remaining after the precipitation and removal of milk casein during cheese-making, represents $85-95 \%$ of the milk volume (Siso, 1996) and its world production is estimated to be over $10^{8}$ tons per year (Grba, Tomas, Stanzer, Vahcic, \& Skrlin, 2002). Biological treatment of whey by conventional aerobic process is very expensive $\approx$ US\$ $0.50 / \mathrm{kg}$ COD (chemical oxygen demand); (Ozmihci \& Kargi, 2007) and most milk plants do not have proper treatment systems for its disposal. As a consequence, around $47 \%$ of the amount produced is disposed of in rivers or lakes, or loaded onto the land, causing serious pollution problems since whey is a heavy organic pollutant with high biochemical oxygen demand (40 g/l to $60 \mathrm{~g} / \mathrm{l}$ ) and COD (50 g/l to $80 \mathrm{~g} / \mathrm{l}$ ) (Athanasiadis, Paraskevopoulou, Blekas, \& Kiosseoglou, 2004). When disposed of on land, it affects the physical and chemical structure of soil, decreasing crop yield; when released into water bodies, it reduces aquatic life by depleting the dissolved oxygen (Panesar, Kennedy, Gandhi, \& Bunko, 2007).

Besides the environmental pollution aspect, dumping of whey constitutes a significant loss of potential food and energy, as whey retains about $55 \%$ of its total milk nutrients. The most abundant of these nutrients are lactose $(45 \mathrm{~g} / \mathrm{l}$ to $50 \mathrm{~g} / \mathrm{l})$, soluble proteins $(6 \mathrm{~g} / \mathrm{l}$

\footnotetext{
* Corresponding author. Tel.: +351 253604 406; fax: +351 253678986.

E-mail address: jateixeira@deb.uminho.pt (J.A. Teixeira).
}

to $8 \mathrm{~g} / \mathrm{l}$ ), lipids ( $4 \mathrm{~g} / \mathrm{l}$ to $5 \mathrm{~g} / \mathrm{l}$ ) and mineral salts ( $8-10 \%$ of dried extract). The mineral salts are comprised of $\mathrm{NaCl}$ and $\mathrm{KCl}$ (more than $50 \%$ ), calcium salts (primarily phosphate) and others. Whey also contains appreciable quantities of lactic $(0.5 \mathrm{~g} / \mathrm{l})$ and citric acids, non-protein nitrogen compounds (urea and uric acid) and B group vitamins (Panesar et al., 2007; Siso, 1996).

Availability of lactose and presence of other essential nutrients for the growth of microorganisms make whey a potential raw material for the production of different bio-products (Panesar et al., 2007). Recent research attempts have tried to develop technologies that employ whey as raw material to produce foods or chemicals of added value, and products such as single-cell proteins, lactic, citric and propionic acids, enzymes, glucose, methane, oligosaccharides, ethanol and others have been proposed (Athanasiadis et al., 2004; Djurić, Carić, Milanović, Tekić, \& Panić, 2004; Koutinas et al., 2007).

The production of an alcoholic beverage by bioconversion of whey is an alternative of great interest for reuse of this industrial by-product. During the last two decades, various research efforts have been done on this theme, and yeasts like Kluyveromyces fragilis and K. marxianus have been proposed as suitable biocatalysts for this bioprocess (Koutinas et al., 2007). Although there are numerous literature reports about alcohol production from whey, most of them are based on the addition of fruit juices, such as mango, banana, pineapple, guava and strawberries, to whey (Kourkoutas et al., 2002). In addition, the scale-up of the process has been little explored and the development of a suitable large-scale procedure for effective utilisation of lactose is still necessary. Moreover, 
information regarding the volatile compounds presents in the distilled drink is scarce, since most of the studies are only concerned in increasing the ethanol yield during fermentation.

Distilled alcoholic beverages are characterised by the presence of volatile compounds (fusel alcohols, fatty acids, esters and others), which arise during fermentation, distillation and storage processes. Identification of these compounds is of major importance, not only to determine the flavor characteristics of the drink, but also to detect illicit spirits, and to identify anomalies that are indicative of inconsistent manufacturing practices (Fitzgerald, James, MacNamara, \& Stack, 2000).

Based on these facts, the goal of the present study was to produce an alcoholic beverage by cheese whey fermentation in a large-scale reactor, using a continuous system, which is more advantageous than batch or fed-batch operations, since labour and cleaning costs are lower, equipment size is reduced; product quality is uniform, with high product yield in less time, increasing process productivity (Ozmihci \& Kargi, 2007; Virkajärvi, Vainikka, Virtanen, \& Home, 2002). The fermented broth was distilled and the volatile compounds present in the produced drink where identified. The organoleptic quality of this drink is discussed and compared with other alcoholic beverages.

\section{Materials and methods}

\subsection{Cheese whey}

Cheese whey ( $\approx 50 \mathrm{~g} / \mathrm{l}$ lactose) obtained from a regional dairy industry (Quinta dos Ingleses, Caíde de Rei, Portugal), was centrifuged ( $2220 \mathrm{~g}$ for $20 \mathrm{~min}$ ) to remove fines and cream, and pasteurised at $65^{\circ} \mathrm{C}$ for $20 \mathrm{~min}$, using a plate heat exchanger. The pasteurised and defatted cheese whey was applied to a $10,000 \mathrm{Da}$ ultrafiltration unit to concentrate the proteins, giving a proteinrich fraction - the concentrate - and a low protein fraction - the permeate. The permeate, with a lactose concentration of $50 \mathrm{~g} / \mathrm{l}$, was kept at $4{ }^{\circ} \mathrm{C}$ in a holding tank before feeding to a $1000 \mathrm{l}$ fermentation vessel.

\subsection{Microorganism and cultivation conditions}

The lactose-fermenting yeast strain Kluyveromyces marxianus ATCC 10022 was the microorganism used in the experiment. The yeast was maintained at $4{ }^{\circ} \mathrm{C}$ on slants containing a medium with the following composition: $\mathrm{KH}_{2} \mathrm{PO}_{4} \quad 5 \mathrm{~g} / \mathrm{l} \quad\left(\mathrm{NH}_{4}\right)_{2} \mathrm{SO}_{4} \quad 2 \mathrm{~g} / \mathrm{l}$, $\mathrm{MgSO}_{4} \cdot 7 \mathrm{H}_{2} \mathrm{O} 0.4 \mathrm{~g} / \mathrm{l}$, yeast extract $1 \mathrm{~g} / \mathrm{l}$, and lactose $20 \mathrm{~g} / \mathrm{l}$.

\subsection{Inoculum and continuous fermentation}

For inoculum preparation, the yeast strain was transferred to $100 \mathrm{ml}$ sterile whey in $500 \mathrm{ml}$ Erlenmeyer flasks. The culture was grown overnight in a rotary shaker, at $30^{\circ} \mathrm{C}$ and $120 \mathrm{rpm}$. In order to inoculate the $1000 \mathrm{l}$ bioreactor, increasing volume inocula (inoculum volume was $1 / 5$ to $1 / 10$ of the volume of the inoculated vessel) were prepared in cheese whey, until a 1001 volume inoculum was obtained.

Continuous experiments were performed in a 10001 stainless steel air-lift bioreactor with 7001 working volume. The bioreactor was filled with pasteurised and deproteinised cheese whey and inoculated with the above mentioned $100 \mathrm{l}$ volume inocula and operated batchwise until residual sugar concentration was negligible. Continuous operation was started by feeding fresh pasteurised and deproteinised whey to the bottom of the reactor with a dilution rate of $0.2 \mathrm{~h}^{-1}$. Pasteurized and deproteinized whey was kept at $4{ }^{\circ} \mathrm{C}$ to avoid any decomposition and was fed to the reactor under aseptic conditions using a centrifuge pump. During the exper- iment, the temperature was maintained at $30^{\circ} \mathrm{C}$ and the $\mathrm{pH}$ was controlled at 4.0 by automatic addition of $\mathrm{H}_{3} \mathrm{PO}_{4}$. The system was aerated with filtered air at a rate of $0.1 \mathrm{vvm}$. The system was kept operating for two months.

\subsection{Distillation}

The fermented broth distillation was carried out in a stainless steel pot still of 5001 (Henrique Vieira \& Filhos Lda, Aveiro, Portugal). The fermented broth was transferred to the vessel up to 3/4 of its capacity in order to be distilled; the distilled product, having an alcoholic grade of approximately $50 \%$, was poured into glass bottles.

\subsection{Analytical methods}

Ethanol was quantified by high-performance liquid chromatography (HPLC), using a Jasco chromatograph equipped with a refractive index (RI) detector (Jasco 830-RI) and a Chrompack column $(300 \times 6.5 \mathrm{~mm})$ at $80^{\circ} \mathrm{C}$, using $5 \mathrm{mM}$ sulfuric acid as the eluent, at a flow rate of $0.3 \mathrm{ml} / \mathrm{min}$ and a sample volume of $20 \mu \mathrm{l}$.

Minor volatile constituents of the whey spirit were determined by extraction with dichloromethane and subsequent analysis of the extracts by gas chromatography-mass spectrometry (GC-MS) using a Varian 3400 chromatograph and an ion-trap mass spectrometer (Varian Saturn II). Samples of $1 \mu$ l were injected in a capillary column coated with CP-Wax $52 \mathrm{CB}(50 \mathrm{~m} \times 0.25 \mathrm{~mm}$ i.d., $0.2 \mu \mathrm{m}$ film thickness; Chrompack). The temperature of the injector (SPI - septum-equipped programmable temperature) was programmed from $20^{\circ} \mathrm{C}$ to $250^{\circ} \mathrm{C}$, at $180^{\circ} \mathrm{C} / \mathrm{min}$. The oven temperature was held at $60^{\circ} \mathrm{C}$, for $5 \mathrm{~min}$, then programmed to rise from $60{ }^{\circ} \mathrm{C}$ to $250{ }^{\circ} \mathrm{C}$, at $3{ }^{\circ} \mathrm{C} / \mathrm{min}$, then held for $20 \mathrm{~min}$ at $250{ }^{\circ} \mathrm{C}$ and finally programmed to go from $250^{\circ} \mathrm{C}$ to $255^{\circ} \mathrm{C}$ at $1{ }^{\circ} \mathrm{C} / \mathrm{min}$. Helium at $103 \mathrm{kPa}$ was used as carrier gas. The detector was set to electronic impact mode $(70 \mathrm{eV})$, with an acquisition range from $\mathrm{m} / \mathrm{z} 29$ to $\mathrm{m} / \mathrm{z} 360$, and an acquisition rate of $610 \mathrm{~ms}$ per scan. Identification of volatiles was performed using the software Saturn version 5.2 (Varian), by comparing mass spectra and retention indices with those of pure standard compounds. All the compounds were quantified as 4-nonanol equivalents.

Major volatile constituents of the whey spirit were analysed directly, without any previous treatment, on a Chrompack CP9000 gas chromatograph equipped with a Split/Splitless injector and a flame ionization detector (FID). A capillary column, coated with CP-Wax 57 CB $(50 \mathrm{~m} \times 0.25 \mathrm{~mm}$ i.d., $0.2 \mu \mathrm{m}$ film thickness; Chrompack), was used. The temperature of the injector and detector were both set to $250^{\circ} \mathrm{C}$. The oven temperature was held at $60{ }^{\circ} \mathrm{C}$, for $5 \mathrm{~min}$, then programmed to rise from $60^{\circ} \mathrm{C}$ to $220^{\circ} \mathrm{C}$, at $3{ }^{\circ} \mathrm{C} / \mathrm{min}$, and finally held at $10 \mathrm{~min}$ at $220^{\circ} \mathrm{C}$. Helium at $103 \mathrm{kPa}$ was used as carrier gas, and the split vent was set to $13 \mathrm{ml} / \mathrm{min}$. Before injection of $1 \mu \mathrm{l}$ in the splitless mode (for $15 \mathrm{~s}), 4$-nonanol was added to the sample (internal standard) to give a final concentration of $213.6 \mathrm{mg} / \mathrm{l}$. Quantification of volatiles, as 4-nonanol equivalents, was performed with CP-Maître software version 2.5 (Chrompack), by comparing retention indices with those of pure standard compounds.

\section{Results and discussion}

It is known that alcoholic fermentation leads to a series of byproducts in addition to ethanol, including carbonyl compounds, alcohols, esters, acids and acetals, all of them influencing the quality of the finished product. The composition and concentration levels of the by-products can vary widely. Some compounds appear in high concentrations (hundreds of $\mathrm{mg} / \mathrm{l}$ ), while a large 
part appear at significantly lower levels (even as low as ng/l) (Plutowska \& Wardencki, 2008). In the present study, the whey spirit produced after fermented broth distillation contained $35.4 \% \mathrm{v} / \mathrm{v}$ ethanol. Another forty volatile compounds were identified, among which, higher alcohols were quantitatively the most abundant group, but several esters, acids, and terpenes were also present. The higher alcohols are normally the group with the highest concentration in distillates, contributing to aroma and essential character (Ferreira, Hernandez-Orte, Escudero, Lopez, \& Cacho, 1999; Silva \& Malcata, 1999). European legislation demands minimum requirements for these aromatic substances of higher than $140 \mathrm{~g} / \mathrm{hl}$ absolute alcohol (AA) (Soufleros, Mygdalia, \& Natskoulis, 2004). In the spirit obtained in our study, the total concentration of higher alcohols was above this minimum requirement, equivalent to $541 \mathrm{~g} / \mathrm{hl} \mathrm{AA}$, thus satisfying European legislation.

Ten compounds (6 higher alcohols, 1 ester, 1 aldehyde, and 2 acids) were identified as major components in whey spirit, with concentration values higher than $6.0 \mathrm{mg} / \mathrm{l}$. The other $30 \mathrm{com}-$ pounds, identified as minor components, included another 7 higher alcohols, 11 esters, 3 aldehydes, 5 acids and 4 terpenes, in concentrations varying from 26.5 to $1740 \mu \mathrm{g} / \mathrm{l}$. The concentration of these compounds depends on the quality and type of the raw materials, as well as the conditions of the fermentation process (Plutowska \& Wardencki, 2008). The effect of volatile compounds on the organoleptic profile of the whey spirit and comparison with other alcoholic distilled beverages are given below.

\subsection{Major volatile compounds in whey spirit}

The GC/FID chromatogram of major volatile compounds present in whey spirit is shown in Fig. 1, and the concentration values of such compounds are given in Table 1. Isoamyl alcohol (3-methyl1-butanol), isobutanol (2-methyl-1-propanol), 1-propanol, and 2-methyl-1-butanol were the higher alcohols found in major quantities. Among the identified esters, ethyl acetate was the most abundant $(138 \mathrm{mg} / \mathrm{l})$, while among the aldehydes, acetaldehyde (36.7 mg/l) was found at the highest concentration. According to some authors (Apostolopoulou, Flouros, Demertzis, \& AkridaDemertzi, 2005; León-Rodríguez, González-Hernández, de la Rosa, Escalante-Minakata, \& López, 2006; Vallejo-Córdoba, GonzálezCórdoba, \& Estrada-Montoya 2004), ethyl esters (mainly ethyl acetate), alcohols with three or more carbon units, and acetaldehyde, are the major agents responsible for the flavor of alcoholic beverages and their amounts determine the quality of the distillate.

Ethyl acetate, for example, has a significant effect on the organoleptic characteristics of distillates. The presence of this ester results in a pleasant aroma with fruity properties, which turns vinegary at levels above $150 \mathrm{mg} / \mathrm{l}$, adding spoilage notes to the beverage (Apostolopoulou et al., 2005; Mingorance-Cazorla, Clemente-Jiménez, Martínez-Rodríguez, Las Heras-Vázquez, \& Rodríguez-Vico, 2003). Thus, the ethyl acetate concentration in whey spirit was at a level suitable to confer a pleasant flavour. Normally, increased ethyl acetate concentrations are indicative of long term storage of the raw material and probable acetic bacterial spoilage (Apostolopoulou et al., 2005; Mingorance-Cazorla et al., 2003).

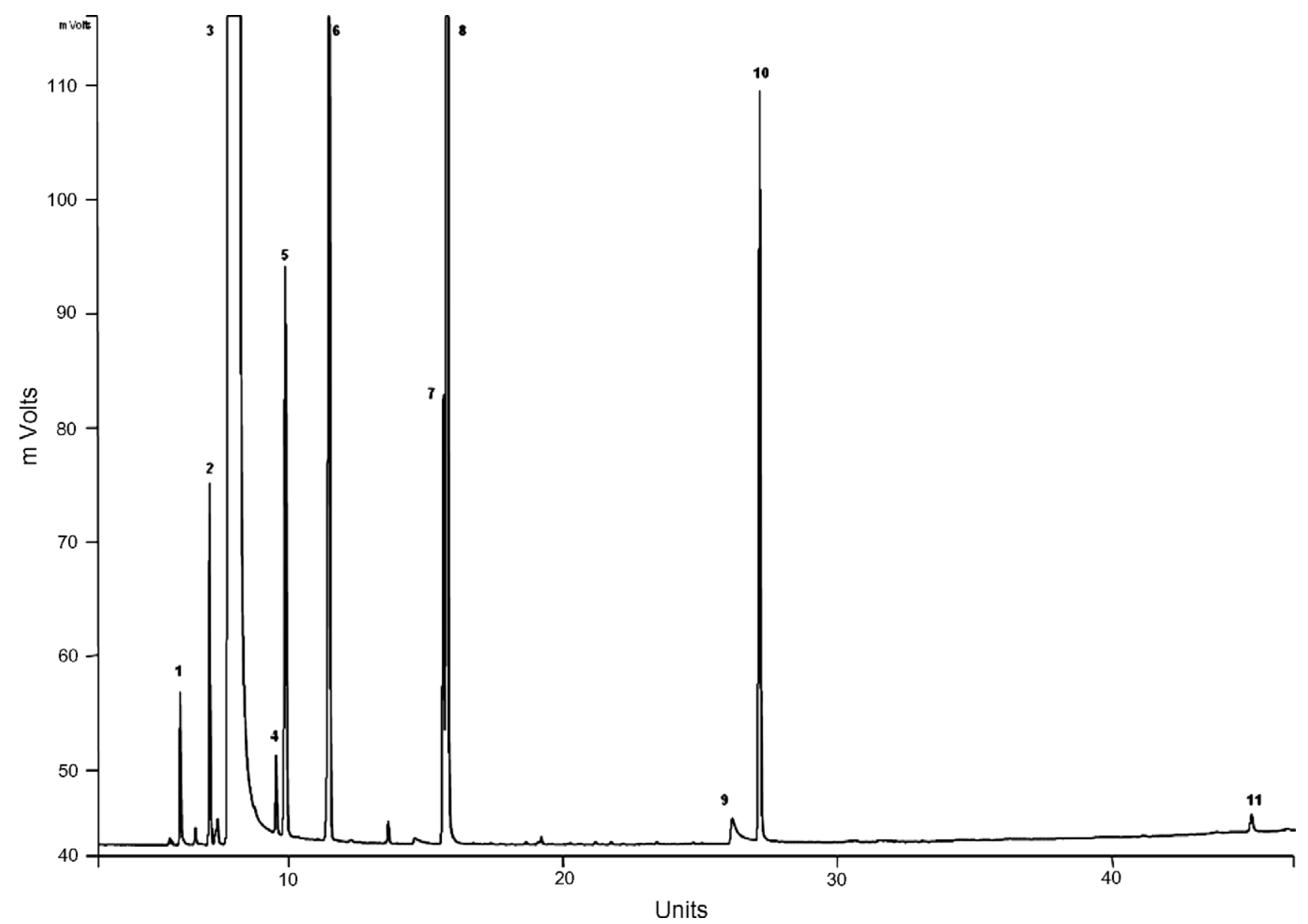

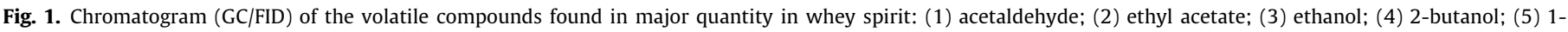
propanol; (6) 2-methyl-1-propanol; (7) 2-methyl-1-butanol; (8) 3-methyl-1-butanol; (9) acetic acid; (10) 4-nonanol (I. S.); (11) 2-phenylethanol. 
Table 1

Concentration of major volatile compounds present in whey spirit by GC/FID, odour threshold and descriptors of each compound

\begin{tabular}{|c|c|c|c|c|}
\hline & & $\begin{array}{l}\text { Concentration } \\
(\mathrm{mg} / \mathrm{l})\end{array}$ & $\begin{array}{l}\text { Odour } \\
\text { threshold } \\
(\mathrm{mg} / \mathrm{l})\end{array}$ & Descriptors \\
\hline Aldehydes & Acetaldehyde & 36.7 & $25^{\mathrm{a}}, \infty$ & $\begin{array}{l}\text { Nutty, sherry- } \\
\text { like }^{\mathrm{b}} \text {; green } \\
\text { leaves }^{\mathrm{a}}\end{array}$ \\
\hline Esters & Ethyl acetate & 138 & $\begin{array}{l}12.3^{\mathrm{c}} \S ; \\
17^{\mathrm{d}}{ }^{*}\end{array}$ & $\begin{array}{l}\text { Solvent, } \\
\text { fruity }^{\mathrm{a}, \mathrm{e}, \mathrm{f}} \text {; nail } \\
\text { polish }^{\mathrm{g}}\end{array}$ \\
\hline \multirow[t]{5}{*}{ Alcohols } & $\begin{array}{l}\text { 2-Methyl-1-butanol } \\
\text { (isopentyl } \\
\text { alcohol) + 3-methyl- } \\
\text { 1-butanol (isoamyl } \\
\text { alcohol) }\end{array}$ & $176+887$ & $7^{\mathrm{c}, \mathrm{d},}$ & $\begin{array}{l}\text { Alcohol, banana, } \\
\text { medicinal, } \\
\text { solvent, } \\
\text { sweetish, } \\
\text { aromatic }^{\mathrm{a}, \mathrm{h}} \text {; } \\
\text { cheese }^{\mathrm{c}}\end{array}$ \\
\hline & $\begin{array}{l}\text { 2-Methyl-1- } \\
\text { propanol (isobutyl } \\
\text { alcohol) }\end{array}$ & 542 & $65^{a} \infty$ & $\begin{array}{l}\text { Alcohol, banana, } \\
\text { medicinal, } \\
\text { solvent }^{\mathrm{a}} \text {; nail } \\
\text { polish }^{\mathrm{g}}\end{array}$ \\
\hline & 1-Propanol & 266 & $750^{a} \infty$ & - \\
\hline & 2-Butanol & 34.7 & $16^{\mathrm{a}} \infty$ & - \\
\hline & 2-Phenylethanol & 7.8 & $\begin{array}{l}7.5^{\mathrm{d}} * \\
14^{\mathrm{c}} \S\end{array}$ & $\begin{array}{l}\text { Rose, sweetish, } \\
\text { perfumed }^{\mathrm{a}} \text {; } \\
\text { roses }^{\mathrm{c}, \mathrm{h}}\end{array}$ \\
\hline Acids & Acetic acid & 79.9 & $300^{c} \S$ & Vinegar ${ }^{c, g}$ \\
\hline
\end{tabular}

* Olfactory perception threshold in hydro-alcoholic solution; §Olfactory threshold in model wine; Olfactory perception threshold in water; $\$$ Olfactory difference threshold in wine; $\infty$ Olfactory difference threshold in beer.

a Meilgaard (1975).

b Fugelsang (1997)

c Escudero et al. (2004).

d Salo (1970).

e Apostolopoulou et al. (2005).

f Mingorance-Cazorla et al. (2003).

g Siebert et al. (2005).

h Falqué et al. (2001).

Besides ethyl acetate, 1-propanol can also be an indicator of bacterial spoilage, because its presence can be a result of possible microbial spoilage during storage under unfavourable conditions of the raw material before distillation (Apostolopoulou et al., 2005). The concentration of 1-propanol in whey spirit was similar to those reported for other distillates, such as tsipouro, grappa, bagaceira, whiskies and cider brandies (Apostolopoulou et al., 2005), suggesting that the whey fermentation and storage were properly controlled. The concentration of 2-methyl-1-propanol in whey spirit can also be well compared with levels in other distilled beverages (Apostolopoulou et al., 2005).

Amyl alcohols (3-methyl-1-butanol and 2-methyl-1-butanol) are formed during fermentation by deamination and decarboxylation reactions from isoleucine and leucine, respectively (Boulton, Singleton, Bisson, \& Kunkee, 1996). Such compounds constitute quantitatively the greater fraction of the higher alcohols in most distilled beverages, being considered predictors of sensory character in the distilled product (Silva, Malcata, \& de Revel, 1996; Soufleros et al., 2004). In the whey spirit produced in our study they were also the higher alcohols found in the highest amounts, with a total concentration of $1063 \mathrm{mg} / \mathrm{l}$ (Table 1), similar to that found in other distillates, such as tsipouro, grappa, wine brandies, bourbon and malt whisky (Apostolopoulou et al., 2005). Increased concentration of amyl alcohols (having an aromatic description of "alcoholic", "sweet" and "choking") can contribute negatively to the aroma of the distillate (Falqué, Fernández, \& Dubourdieu, 2001).

The same discussion can be used for 2-phenylethanol. This compound, which introduces a pleasant aroma to distillates, described as "rose-like", "sweet" and "perfume-like", has a positive influence on the aroma of beverages when present at low concentrations
(Falqué et al., 2001). In whey spirit, 2-phenylethanol was found at a concentration of $7.8 \mathrm{mg} / \mathrm{l}$, equivalent to $2.20 \mathrm{~g} / \mathrm{hl} \mathrm{AA}$. A very similar value $(2.22 \mathrm{~g} / \mathrm{hl} \mathrm{AA})$ was observed for samples of bagaceiras (Silva et al., 1996); while in whiskey (Fitzgerald et al., 2000) and aguardiente samples (Rogerson \& de Freitas, 2001), lower concentration values were detected, corresponding to $1.44 \mathrm{~g} / \mathrm{hl} \mathrm{AA}$ and up to $1.8 \mathrm{~g} / \mathrm{hl} \mathrm{AA}$, respectively. Higher concentrations of 2-phenylethanol were found in the Greek distillates tsipouro ( 2.8 up to $23.4 \mathrm{~g} /$ hl AA) and mouro (between traces and $12.7 \mathrm{~g} / \mathrm{hl} \mathrm{AA}$ ) (Soufleros et al., 2004).

Low molecular mass carbonyls such as aldehydes and ketones are normally found in alcoholic beverages as by-products of yeast fermentation, intermediates in the formation of fusel oil and as a result of alcohol oxidation at various stages of beverage production. Nevertheless, their presence is not desirable because some of them are responsible for unpleasant organoleptic properties (Wardencki, Sowinski, \& Curylo, 2003). In the present study, acetaldehyde was the only carbonyl identified among the major volatile compounds, but its concentration value, $36.7 \mathrm{mg} / \mathrm{l}$, was low when compared to other alcoholic distillates, such as tsipouro or grappa (Apostolopoulou et al., 2005). This low concentration value is interesting, because elevated acetaldehyde concentrations give a pungent irritating odour to the beverage, and can be health hazards (Geroyiannaki et al., 2007). On the other hand, at low concentrations, the sensory descriptors for acetaldehyde range from "classic", "nutty" and "sherry like" to being reminiscent of overripe bruised apples (Fugelsang, 1997).

The acetaldehyde concentration in whey spirit was approximately 24-fold lower than the concentration of the higher alcohol found in largest amount (3-methyl-1-butanol, $887 \mathrm{mg} / \mathrm{l}$ ). In a more general aspect, the total aldehydes concentration was $36.88 \mathrm{mg} / \mathrm{l}$, 52 -fold lower than the total concentration of higher alcohols present in this beverage. Such results suggest that the aldehydes found in whey spirit should not negatively affect the organoleptic quality of this alcoholic beverage.

In general, the compounds identified in major quantity in whey spirit are similar to those present in other alcoholic beverages, like sake, mouro, or mescal produced from Agave salmiana, for example. The major volatile components in sake included 2-methyl-1propanol, 3-methyl-1-butanol, propanol, ethyl acetate, isoamyl acetate, and acetaldehyde (Teramoto, Yoshida, \& Ueda, 2002). In mescal propanol, 2-butanol, 2-methyl-1-propanol, 2-methyl-1butanol, 3-methyl-1-butanol, methanol, acetic acid, ethyl 2hydroxypropanoate and ethyl acetate were identified as major components (León-Rodríguez et al., 2006). The main volatile components in mouro included methanol, 3-methyl-1-butanol, 2methyl-1-butanol, acetaldehyde and ethyl acetate (Soufleros et al., 2004).

It should be pointed out that methanol was not found (by GC/ FID) in whey spirit, that is benefic since a highly toxic effect has been reported for this compound (maximum legal limit $1000 \mathrm{~g} / \mathrm{hl}$ of 100\% vol. ethanol - Council Regulation (EEC) No. 1576/89, 1989), whose ingestion or inhalation can cause blindness or death (Geroyiannaki et al., 2007). Methanol is formed from pectin by pectolytic enzymes, which hydrolyse the methoxyl group during fermentation (Apostolopoulou et al., 2005; Soufleros et al., 2004). Therefore, the absence of methanol in whey spirit is probably due to the lack of pectin in cheese whey.

\subsection{Minor volatile compounds in whey spirit}

Fig. 2 and Table 2 list the 30 compounds identified as minor components in whey spirit, and their concentrations. Despite the low concentration of minor compounds, their presence is relevant because they harmonically synergise to produce the characteristic beverage aroma (León-Rodríguez et al., 2006). Wines, for example, 
contain small quantities of organic acids but they contribute sufficiently to the aroma of this beverage (Mingorance-Cazorla et al., 2003). In alcoholic beverages in general, compounds appearing in trace quantities, quite frequently, have a greater influence on their sensory properties than those compounds that appear in high concentrations (Plutowska \& Wardencki, 2008).

It can be noted in Table 2 that an abundant group of ethyl esters was detected among the minor volatile components in whey drink. According to Mingorance-Cazorla et al. (2003) the yeast used in the fermentation process has a great influence on ester production. The ethyl esters in general are compounds associated with the bouquet and pleasant fruity flavours and floral aroma, and they have been detected in other alcoholic beverages such as tequila, mescal, mouro, wine, beers and others (Gandini \& Riguzz, 1997; Jelen, Wlazly, Wazowicz, \& Kaminski, 1998; León-Rodríguez et al., 2006; Soufleros et al., 2004; Vallejo-Córdoba et al., 2004). Besides the flavour characteristics, the ethyl lactate ester, in particular, is able to stabilise the distillate flavour and softens the harsh flavour characteristics when present at low concentrations (Apostolopoulou et al., 2005). Three of the ethyl esters identified in whey spirit, namely, hexanoate, octanoate, and decanoate, are considered to make a small participation compared to the other volatile com- pounds and add to the complexity of the spirits (Ferreira et al., 1999). On the other hand, isoamyl acetate and phenylethyl acetate, also present in the whey drink, are mainly responsible for the floral and fruity aroma of the distillates (Ferreira et al., 1999).

Several higher alcohols were also identified among the minor volatile components in whey drink, 1-hexanol being the compound present in the highest quantity. This alcohol has a positive influence on the aroma of the distillate when it occurs in concentrations up to $20 \mathrm{mg} / \mathrm{l}$. On the contrary, increased concentration of 1-hexanol, having an aromatic description of "coconut-like", "harsh" and "pungent", can contribute negatively to the product aroma. At even higher levels the organoleptic characteristics of the distillate are seriously impaired (Falqué et al., 2001). The low 1-hexanol concentration found in whey spirit $(\approx 0.6 \mathrm{mg} / \mathrm{l})$ can be considered to affect positively the flavor of the product.

Besides ethyl esters and higher alcohols, the minor components in whey distillate also included some aldehydes, acids and terpenes. Among the aldehydes, furfural was identified at a high proportion. This compound is formed during distillation, due to degradation of fermentable pentose sugars, caused by heating in acid conditions and/or Maillard reaction (Mangas, Rodríguez, Moreno, \& Blanco, 1996). Thus, high amounts of furfural might

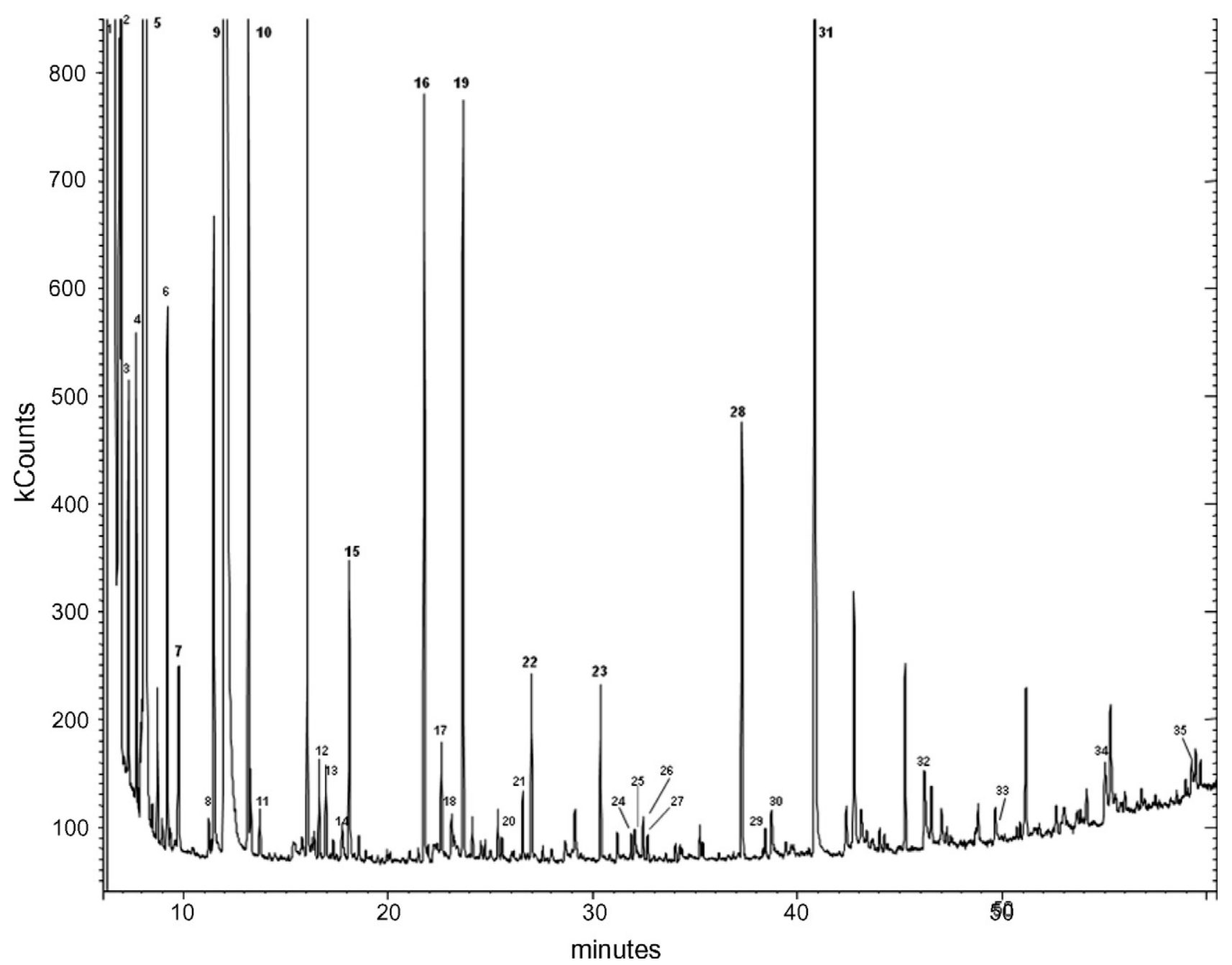

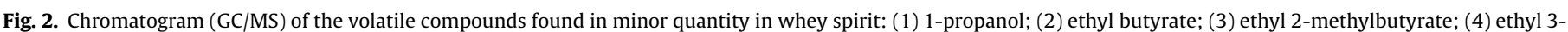

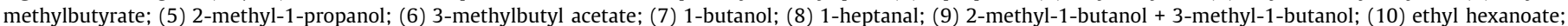

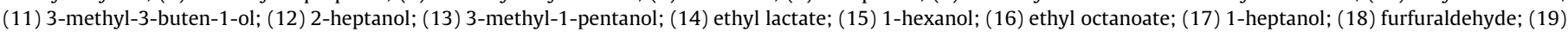

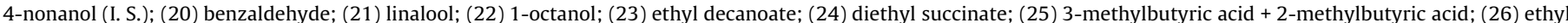

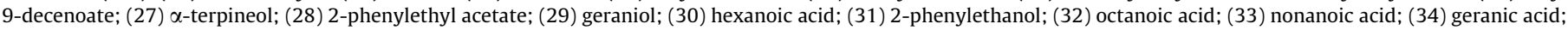
(35) dodecanoic acid. 
Table 2

Concentration of minor volatile compounds present in whey spirit by GC/MS, odour threshold and descriptors of each compound

\begin{tabular}{|c|c|c|c|c|}
\hline & & Concentration $(\mu \mathrm{g} / \mathrm{l})$ & Odour threshold $(\mu \mathrm{g} / \mathrm{l})$ & Descriptors \\
\hline Aldehydes & $\begin{array}{l}\text { Furfural } \\
\text { Benzaldehyde } \\
\text { Heptanal }\end{array}$ & $\begin{array}{l}101.1 \\
49.3 \\
26.5\end{array}$ & $\begin{array}{l}88,000^{\mathrm{a}} \S \\
2000^{\mathrm{b}} \infty \\
-\end{array}$ & $\begin{array}{l}\text { Paper }^{\mathrm{b}} \text {; sweet } \\
\text { - } \\
-\end{array}$ \\
\hline Esters & $\begin{array}{l}\text { Ethyl butanoate (ethyl butyrate) } \\
\text { Ethyl hexanoate (ethyl caproate) } \\
\text { Ethyl octanoate (ethyl caprylate) } \\
\text { Phenylethyl acetate } \\
\text { 3-Methylbutyl acetate (isoamyl acetate) } \\
\text { Ethyl 3-methylbutanoate } \\
\text { Ethyl 2-methylbutanoate } \\
\text { Ethyl decanoate (ethyl caprate) } \\
\text { Ethyl 2-hydroxypropanoate (ethyl lactate) } \\
\text { Ethyl 9-decenoate } \\
\text { Diethyl succinate (diethyl butanedioic acid) }\end{array}$ & $\begin{array}{l}1740 \\
1420 \\
1320 \\
876 \\
831 \\
541 \\
467 \\
302 \\
83.3 \\
76.2 \\
42.4\end{array}$ & $\begin{array}{l}20^{\mathrm{a}} \S \\
14^{\mathrm{a}} \S \\
5^{\mathrm{a}} \S ; 250^{\mathrm{e},} \\
650^{\mathrm{e}}, \\
30^{\mathrm{a}} \S ; 200^{\mathrm{e}^{*}} \\
3^{\mathrm{a}} \S \\
18^{\mathrm{a}} \S \\
200^{\mathrm{a}} \S \\
14,000^{\mathrm{e}} \\
- \\
75000^{\mathrm{g}}\end{array}$ & 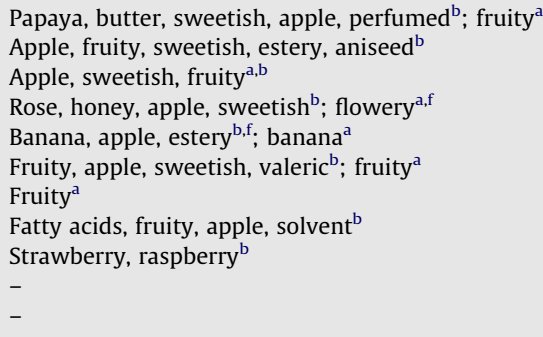 \\
\hline Alcohols & $\begin{array}{l}\text { 1-Hexanol } \\
\text { 1-Butanol } \\
\text { 1-Octanol } \\
\text { 1-Heptanol } \\
\text { 3-Methyl-1-pentanol } \\
\text { 2-Heptanol } \\
\text { 3-Methyl-3-buten-1-ol }\end{array}$ & $\begin{array}{l}592 \\
352 \\
345 \\
207 \\
181 \\
169 \\
88.5\end{array}$ & $\begin{array}{l}5200^{e^{*}} ; \\
150,000^{\mathrm{i}} \\
900^{\mathrm{b}} \infty \\
- \\
- \\
- \\
-\end{array}$ & $\begin{array}{l}\text { Coconut, green leaves, unpleasant } \\
\text { Alcohol }^{\mathrm{b}} \text {; fusel } \\
\text { Coconut, walnut, oily }^{\mathrm{b}} \\
- \\
- \\
- \\
-\end{array}$ \\
\hline Acids & $\begin{array}{l}\text { Octanoic acid (caprylic acid) } \\
\text { Hexanoic acid (caproic acid) } \\
\text { 3-Methylbutanoic acid + 2-methylbutanoic acid } \\
\text { Dodecanoic acid (lauric acid) } \\
\text { Nonanoic acid (pelargonic acid) }\end{array}$ & $\begin{array}{l}280 \\
133 \\
75.7 \\
57.2 \\
26.9\end{array}$ & $\begin{array}{l}500^{\mathrm{a}} \S \\
420^{\mathrm{a}} \S \\
- \\
6100^{\mathrm{b}} \infty \\
-\end{array}$ & $\begin{array}{l}\text { Goaty, fatty acid, vegetable oil, wet } \text { dog }^{\mathrm{b}} \\
\text { Goaty, fatty acid, vegetable oil, sweaty }{ }^{\mathrm{b}} \text { green }^{\mathrm{a}} \\
\text { - } \\
\text { Fatty acid }{ }^{\mathrm{c}} \text {; soapy, waxy } \\
\text { - }\end{array}$ \\
\hline Terpenes & $\begin{array}{l}\text { Geranic acid } \\
\text { Linalool } \\
\text { Geraniol } \\
\alpha \text {-Terpineol }\end{array}$ & $\begin{array}{l}171 \\
110 \\
55.5 \\
49.5\end{array}$ & $\begin{array}{l}- \\
25^{\mathrm{a}} \S \\
36^{\mathrm{a}} \S \\
330^{\mathrm{a}} \S\end{array}$ & $\begin{array}{l}\text { Aniseed, terpenoid }{ }^{\mathrm{b}} ; \text { roses }^{\mathrm{k}} \text {; lemon } \\
\text { Roses }^{\mathrm{k}} \\
\text { Pine, terpenoid }^{\mathrm{b}}\end{array}$ \\
\hline
\end{tabular}

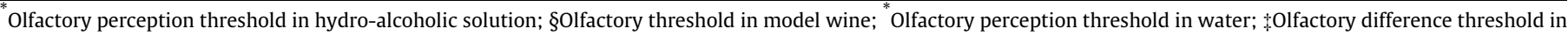
wine; $\infty$ Olfactory difference threshold in beer.

a Escudero et al. (2004).

b Meilgaard (1975).

c Cullere, Escudero, Cacho, and Ferreira (2004).

d Apostolopoulou et al. (2005).

e Salo (1970).

${ }^{f}$ Ferreira et al. (1999).

g Shinohara (1984).

h Falqué et al. (2001).

i Shinohara and Watanabe (1976).

j Siebert et al. (2005).

k Ribéreau-Gayon, Glories, Maujean, and Dubourdieu (2000).

be attributed to the presence of high quantities of residual pentose sugars, due to unfavourable fermentation conditions of the substrate (Apostolopoulou et al., 2005). Its odour is reminiscent of bitter almond and cinnamon and it has a toxic character. Therefore, it should be present in distillates only in low concentrations. Furfural concentration in whey spirit was very low $(\approx 0.1 \mathrm{mg} / \mathrm{l})$, much lower than that found in tsipouros, for example (Apostolopoulou et al., 2005).

The acids identified among the minor volatile components in whey spirit included long-chain fatty acids such as hexanoic, octanoic, nonanoic and dodecanoic acids, which are considered to have low flavour effect in the distillates (Soufleros et al., 2004). Table 2 shows their concentrations in the beverage obtained in this study. Such values were lower than those observed for other distilled drinks, such as bagaceiras (Silva et al., 1996), aguardiente (Rogerson \& de Freitas, 2001), and mouro (Soufleros et al., 2004).

Four terpenes were identified in the whey-based drink, including geranic acid, linalool, geraniol, and $\alpha$-terpineol. The terpenes can originate from the raw material (Peña-Alvarez et al., 2004) or liberated by $\alpha$-glycosidases from yeasts during the fermentation process (King \& Dickinson, 2000, 2003). The terpenes content is considered to be a positive quality factor of a beverage because terpenes contribute to its aroma, serving to differentiate it from other beverages, and supply floral nuances to the drink (Calleja \& Falqué, 2005; Falqué et al., 2001). In whey spirit, linalool for example, was found at a concentration of $110 \mu \mathrm{g} / \mathrm{l}$, a value well above its perception threshold of $25 \mu \mathrm{g} / \mathrm{l}$ (Escudero et al., 2004).

\section{Conclusions}

This work revealed the presence of forty volatile compounds in the alcoholic distilled beverage produced by continuous fermentation of whey with Kluyveromyces marxianus. Most of these compounds are similar to those reported for other alcoholic beverages, although the concentration values are different. Higher alcohols (mainly isoamyl alcohol, isobutanol, and 1-propanol) and ethyl esters (mainly ethyl acetate) were the most dominant compounds present, contributing thus for the greatest proportion of the total aroma. Some short and long chain fatty acid esters that contribute to fruity and flowery aroma were also present, and the volatile compounds that can be harmful to the health (methanol, acetaldehyde and ethyl acetate) were found at low levels. Considering that the quality of alcoholic beverages such as whisky, can be evaluated by the relation between isoamyl alcohol/2-methyl-1propanol and 2-methyl-1-propanol/1-propanol, which have to be higher than unity (Rodríguez Mendiola \& de la Serna Torroba, 
2000), it was concluded that a novel spirit of acceptable organoleptic character can be produced by continuous fermentation of cheese whey with $K$. marxianus.

\section{Acknowledgment}

The authors thank Quinta dos Ingleses for supplying the cheese whey, and Eng. Azevedo Lemos for his technical support.

\section{References}

Apostolopoulou, A. A., Flouros, A. I., Demertzis, P. G., \& Akrida-Demertzi, K. (2005) Differences in concentration of principal volatile constituents in traditional Greek distillates. Food Control, 16, 157-164.

Athanasiadis, I., Paraskevopoulou, A. Blekas, G., \& Kiosseoglou, V. (2004) Development of a novel whey beverage by fermentation with kefir granules. Effect of various treatments. Biotechnology Progress, 20, 1091-1095.

Boulton, R. B., Singleton, V. L., Bisson, L. F., \& Kunkee, R. E. (1996). Principles and practices of winemaking. New York: Chapman \& Hall.

Calleja, A., \& Falqué, E. (2005). Volatile composition of Mencía wines. Food Chemistry, 90, 357-363.

Council Regulation (EEC) No. 1576/89 (1989). Laying down general rules on the definition, description and presentation of spirit drinks. Official Journal of European Community, L160, 1-17.

Cullere, L., Escudero, A., Cacho, J., \& Ferreira, V. (2004). Gas chromatographyolfactometry and chemical quantitative study of the aroma of six premium quality Spanish aged red wines. Journal of Agricultural and Food Chemistry, 52, 1653-1660.

Djurić, M., Carić, M., Milanović, S., Tekić, M., \& Panić, M. (2004). Development of whey-based beverages. European Food Research and Technology, 219, 321-328.

Escudero, A., Gogorza, B., Melus, M. A., Ortin, N., Cacho, J., \& Ferreira, V. (2004) Characterization of the aroma of a wine from Maccabeo. Key role played by compounds with low odor activity values. Journal of Agricultural and Food Chemistry, 52, 3516-3524.

Falqué, E., Fernández, E., \& Dubourdieu, D. (2001). Differentiation of white wines by their aromatic index. Talanta, 54, 271-281.

Ferreira, V., Hernandez-Orte, P., Escudero, A., Lopez, R., \& Cacho, J. (1999). Semipreparative reversed-phase liquid chromatographic fractionation of aroma extracts from wine and other alcoholic beverages. Journal of Chromatography A, 864, 77-88.

Fitzgerald, G., James, K. J., MacNamara, K., \& Stack, M. A. (2000). Characterization of whiskeys using solid-phase microextraction with gas chromatography-mass spectrometry. Journal of Chromatography A, 896, 351-359.

Fugelsang, K. C. (1997). Wine microbiology. New York: Chapman \& Hall.

Gandini, N., \& Riguzz, R. (1997). Headspace solid-phase microextraction analysis of methyl isothiocyanate in wine. Journal of Agricultural and Food Chemistry, 45, 3092-3094.

Geroyiannaki, M., Komaitis, M. E., Stavrakas, D. E., Polysiou, M., Athanasopoulos, P. E., \& Spanos, M. (2007). Evaluation of acetaldehyde and methanol in greek traditional alcoholic beverages from varietal fermented grape pomaces (Vitis vinifera L.). Food Control, 18, 988-995.

Grba, S., Tomas, V. S., Stanzer, D., Vahcic, N., \& Skrlin, A. (2002). Selection of yeast strain Kluyveromyces marxianus for alcohol and biomass production on whey. Chemical and Biochemical Engineering Quarterly, 16, 13-16.

Jelen, H. H., Wlazly, K., Wazowicz, E., \& Kaminski, E. (1998). Solid-phase microextraction for the analysis of some alcohols and esters in beers: Comparison with static headspace method. Journal of Agricultural and Food Chemistry, 46, 1469-1743.

King, A., \& Dickinson, J. R. (2000). Biotransformation of monoterpene alcohols by Saccharomyces cerevisiae, Torulaspora delbrueckii and Kluyveromyces lactis. Yeast, $16,499-506$.

King, A. J., \& Dickinson, J. R. (2003). Biotransformation of hop aroma terpenoids by ale and lager yeasts. FEMS Yeast Research, 3, 53-62.

Kourkoutas, Y., Psarianos, C., Koutinas, A. A., Kanellaki, M., Banat, I. M., \& Marchant R. (2002). Continuous whey fermentation using kefir yeast immobilized on delignified cellulosic material. Journal of Agricultural and Food Chemistry, 50, 2543-2547.

Koutinas, A. A., Athanasiadis, I., Bekatorou, A., Psarianos, C., Kanellaki, M., Agouridis, N., \& Blekas, G. (2007). Kefir-yeast technology: Industrial scale-up of alcoholic fermentation of whey, promoted by raisin extracts, using kefir-yeast granular biomass. Enzyme and Microbial Technology, 41, 576-582.

León-Rodríguez, A., González-Hernández, L., de la Rosa, A. P. B., Escalante-Minakata, P., \& López, M. G. (2006). Characterization of volatile compounds of mezcal, an ethnic alcoholic beverage obtained from Agave salmiana. Journal of Agricultural and Food Chemistry, 54, 1337-1341.

Mangas, J., Rodríguez, R., Moreno, J., \& Blanco, D. (1996). Changes in the major volatile compounds of cider distillates during maturation. Lebensmittel Wissenschaft und-Technologie, 29, 357-364.

Meilgaard, M. C. (1975). Flavor chemistry of beer: Part II: Flavor and threshold of 239 aroma volatiles. MBAA Technical Quarterly, 12, 151-168.

Mingorance-Cazorla, L., Clemente-Jiménez, J. M., Martínez-Rodríguez, S., Las HerasVázquez, F. J., \& Rodríguez-Vico, F. (2003). Contribution of different natural yeasts to the aroma of two alcoholic beverages. World Journal of Microbiology and Biotechnology, 19, 297-304.

Ozmihci, S., \& Kargi, F. (2007a). Effects of feed sugar concentration on continuous ethanol fermentation of cheese whey powder solution (CWP). Enzyme and Microbial Technology, 41, 876-880.

Ozmihci, S., \& Kargi, F. (2007b). Kinetics of batch ethanol fermentation of cheesewhey powder (CWP) solution as function of substrate and yeast concentrations. Bioresource Technology, 98, 2978-2984.

Panesar, P. S., Kennedy, J. F., Gandhi, D. N., \& Bunko, K. (2007). Bioutilisation of whey for lactic acid production. Food Chemistry, 105, 1-14.

Peña-Alvarez, A., Diáz, L., Medina, A., Labastida, C., Capella, S., \& Vera, L. E. (2004). Characterization of three Agave species by gas chromatography and solidphase-gas chromatography-mass spectrometry. Journal of Chromatography A, 1027, 131-136.

Plutowska, B., \& Wardencki, W. (2008). Application of gas chromatographyolfactometry (GC-O) in analysis and quality assessment of alcoholic beverages - A review. Food Chemistry, 107, 449-463.

Ribéreau-Gayon, P., Glories, Y., Maujean, A., \& Dubourdieu, D. (2000). Varietal aroma. Handbook of enology. The chemistry of wine and stabilization and treatments (Vol. 2, pp. 187-206). New York: John Wiley and Sons Ltd.

Rodríguez Mendiola, I., \& de la Serna Torroba, P. (2000). Los whiskies escoceses. Estudio analítico de sus componentes volátiles por cromatografía de gases. Alimentaria, 316, 139-146.

Rogerson, F. S. S., \& de Freitas, V. A. P. (2001). Quantitative analysis of volatiles present in wine spirits used for port production. In ASEV 52nd Annual Meeting, San Diego, CA.

Salo, P. (1970). Determining the odor thresholds for some compounds in alcoholic beverages. Journal of Food Science, 35, 95-99.

Shinohara, T. (1984). L'importance des substances volatiles du vin. Formation et effets sur la qualité. Bulletin de l'O. I. V.(641/642), 606-618.

Shinohara, T., \& Watanabe, M. (1976). Gas chromatographic analysis of higher alcohols and ethyl acetate in table wines. Agricultural and Biological Chemistry, 40, 2475-2477.

Siebert, T. E., Smyth, H. E. Capone, D. L, Neuwöhner, C. Pardon, C. H. Skouroumounis, G. K., Herderich, M. J., Sefton, M. A., \& Pollnitz, A. P. (2005). Stable isotope dilution analysis of wine fermentation products by HS-SPMEGC-MS. Analytical and Bioanalytical Chemistry, 381, 937-947.

Silva, M. L., \& Malcata, F. X. (1999). Effects of time of grape pomace fermentation and distillation cuts on the chemical composition of grape marcs. Zeitschrift für Lebensmittel Untersuchung und-Forschung A, 208, 134-143.

Silva, M. L., Malcata, F. X., \& de Revel, G. (1996). Volatile contents of grape marcs in Portugal. Journal of Food Composition and Analysis, 9, 72-80.

Siso, M. I. G. (1996). The biotechnological utilization of cheese whey: A review. Bioresource Technology, 57, 1-11.

Soufleros, E. H., Mygdalia, A. S., \& Natskoulis, P. (2004). Characterization and safety evaluation of the traditional Greek fruit distillate "Mouro" by flavor compounds and mineral analysis. Food Chemistry, 86, 625-636.

Teramoto, Y., Yoshida, S., \& Ueda, S. (2002). Characteristics of a rice beer (zutho) and a yeast isolated from the fermented product in Nagaland, India. World Journal of Microbiology and Biotechnology, 18, 813-816.

Vallejo-Córdoba, B., González-Córdoba, A. F., \& Estrada-Montoya, M. C. (2004). Tequila volatile characterization and ethyl ester determination by solid-phase microextraction gas chromatography/mass spectrometry analysis. Journal of Agricultural and Food Chemistry, 52, 5567-5571.

Virkajärvi, I., Vainikka, M., Virtanen, H., \& Home, S. (2002). Productivity of immobilized yeast reactors with very-high-gravity wort. Journal of the American Society of Brewing Chemists, 60, 188-197.

Wardencki, W., Sowinski, P., \& Curylo, J. (2003). Evaluation of headspace solid-phase microextraction for the analysis of volatile carbonyl compounds in spirits and alcoholic beverages. Journal of Chromatography A, 984, 89-96. 